\title{
WILL THE IMPLEMENTATION OF A TOTAL QUALITY MANAGEMENT SYSTEM BENEFIT SOUTH AFRICAN CONSTRUCTION COMPANIES?
}

\author{
W Joubert ${ }^{1}$, JH Cruywagen ${ }^{2}$ and GAJ Basson ${ }^{3}$ \\ 2, 3 Department of Construction Economics, \\ University of Pretoria, South Africa. \\ 1wessel@nmc.co.za, ${ }^{2}$ edutech@asaqs.co.za ${ }^{3}$ gert.basson@up.ac.za
}

\begin{abstract}
The increased levels of competition experienced in recent times in the construction sector due to globalisation and the economic downturn highlighted the need for South African construction companies to be more competitive. This paper investigates the reasons for poor quality in the South African construction industry and whether the implementation of a Total Quality Management system in this industry will improve the situation.
\end{abstract}

\section{OPSOMMING}

Die hoër vlakke van kompetisie wat gedurende die afgelope tydperk in die konstruksiebedryf ervaar is as gevolg van globalisering en die afswaai in die ekonomie, het die behoefte laat ontstaan dat Suid-Afrikaanse konstruksiemaatskappye meer mededingend moes raak. Hierdie artikel ondersoek die redes vir swak kwaliteit in die Suid-Afrikaanse konstruksiebedryf en of die implementering van ' $n$ Totale Kwaliteitsbestuurstelsel sal bydra om die situasie te verbeter.

\footnotetext{
${ }^{1}$ The author was enrolled for the MSc (Project Management) at the Department of Construction Economics, University of Pretoria.
} 


\section{INTRODUCTION}

The rise in interest rates of 1998 had a catastrophic influence on the construction sector of the South African economy. Many companies did not survive the effect of this period, and those who did, found themselves locked in desperate competition with the remaining companies. Membership of the global economy, and the need to hedge income through work in foreign economies as found in Africa and the Middle East, also implied that the South African companies were competing with foreign companies. To counter this intense competition, South African construction companies had to become more competitive both locally and abroad.

To become more competitive, a company needs to distinguish itself from its rivals. This should also ensure a good name resulting in follow-up work from satisfied customers and negotiated work through becoming a preferred bidder. One way to achieve this is by improving the quality of the company's product.

\section{QUALITY}

What is "quality"? Ahmed [1] quotes ISO 8402 in defining quality as “...the degree of excellence in a competitive sense, such as reliability, serviceability, maintainability or even individual characteristics". In the modern economy, quality has therefore become a process whereby future products are improved to satisfy (or exceed) customer needs and expectations.

When considering quality improvement, it is important to recognise that there is a definite link between quality and productivity. Quality improvement is aimed at doing things better with the same resources, while productivity improvement is aimed at doing the same work with fewer resources. It is, subsequently, easier to motivate personnel towards quality improvements than towards productivity improvements, because quality improvements do not appear to endanger their employment [15].

According to Verster [16] one of the barriers to quality in the construction industry is the fact that contractors are expected to deliver products of certain standards (embodied in specifications) within extremely tight time constraints.

Due to their intimate involvement in the process, clients in the construction industry have a much larger influence on the quality of the product than is the case in pure manufacturing. Verster [16] mentions that owners, or clients, want returns within certain time frames and often sell developments within a short period of time. Long-term commitment is therefore not always present.

Current methods of result-oriented quality control have, to a degree, become entrenched in the construction contract law. Retention money, as a method of ensuring quality, is still commonplace, even though modern contracts tend to steer clear of it. The problem with this approach is that it is retroactive and only reveals what has already gone wrong. The fact remains that quality cannot be inspected into a product.

One of the main motivators for improving quality comes from the calculation of the cost of quality. The cost of quality is the cost that would not have been incurred if the quality of the 
product was satisfactory. The difficulty in determining the cost of quality has hampered its use. The cost of quality is a vital management tool that consists of prevention costs, appraisal costs and internal- and external failure costs [11]. The total cost of quality will be minimised when the costs to ensure good quality are balanced with the cost to rectify poor quality.

\section{PROBLEMS PERTAINING TO POOR QUALITY IN THE SOUTH AFRICAN CONSTRUCTION INDUSTRY}

Verster [16] argues that, although the principles of producing quality are universal, the construction industry differs in many aspects from the manufacturing industry.

A number of people have done research on the management of quality and the implementation of Total Quality Management (TQM) in construction in South Africa. Some of the biggest problems identified are the following:

\section{Commitment by top management.}

Grobbelaar [3] and Ngowi [10] both state that top management of construction companies, both in South Africa and Botswana, do not show commitment to quality or TQM and that the focus of the company is more towards maximising profit and saving time. Furthermore, management's commitment is either not clearly communicated to workers or workers do not have access to the quality policy and quality goals of the company and therefore do not have the motivation to deliver a quality product.

\section{Training of skilled and unskilled workers.}

One of the main reasons for poor quality in the South African construction industry is that the workers who are responsible for the physical execution of projects, and therefore also for the quality thereof, do not have sufficient training to deliver the expected results [3]. Zietsman [17] is of the opinion that companies either do not have the time to invest in workers' training, or they are unwilling to do so because the workers are contracted on a project-to-project basis and therefore it is uncertain how long the workers are going to be in employment. Grobbelaar [3] also mentions that the cost to train workers may be considered an unnecessary expense. Zietsman [17] found that in South Africa there is very little, if any, correlation between the performance of workers and their remuneration and that this also contributes thereto that workers do not strive to produce a product of high quality.

\section{The use of subcontractors}

Zietsman [17] mentions that main contractors found that the increasing use of subcontractors leads to fragmentation of the process, with the result that such subcontractors perform their tasks almost in isolation. A subcontractor's aim is to complete his part of the work as quickly as possible, to use as little expensive labour as possible and to get remuneration as soon as possible. This is not conducive to good quality. 


\section{Monitoring and supervision}

Both Grobbelaar [3] and Zietsman [17] found that a shortage of trained and experienced supervising personnel results in a situation where monitoring and supervision do not take place on a regular basis and therefore defects are not identified at an early stage. This leads to the continuous rectification of defective work.

\section{Tenders}

In his study, Zietsman [17] found that the practice where tenders are awarded solely on price also has an influence on the quality of projects.

\section{Culture}

Ngowi [10] conducted a study on the application of TQM in the construction industry in Botswana. As a result of Botswana's proximity to South Africa, many of the following findings in this study will be applicable to the South African construction industry.

Ngowi [10] found that society in Botswana tends to be fatalistic rather than deterministic. As a result of this a culture exists which is largely contrary to a TQM culture:

- Workers do not take responsibility for their own actions as dictated by TQM principles and tend to believe all responsibility rests with management.

- Where TQM places emphasis on prevention rather than detection, Botswana workers leave initiatives towards preventive measures to higher authorities.

- Societies in Botswana (traditionally administrated by Chiefs) are more prescriptive than achievement orientated and therefore workers do not aspire to achieve awards - one of the aspects strongly emphasized by TQM.

- Also because of their fatalistic nature, workers feel that problems such as quality are beyond their ability and should be solved by management.

- Most workers on construction projects are recruited on a project basis and therefore do not spend much time with one company. This hampers another important element of TQM namely that of employee empowerment to make decisions at their level of operation.

\section{SURVEY}

To test the above findings of previous studies, a limited survey was carried out.

\section{Methodology}

The survey targeted small to medium sized construction companies and was done by means of questionnaires that were distributed to and completed by ten companies doing business either in the Pretoria or Port Elizabeth areas.

\section{Results.}

The results of the questionnaires are shown in the following table: 


\begin{tabular}{|c|c|c|c|c|}
\hline No & Question & Yes & & No \\
\hline 1 & $\begin{array}{l}\text { Does your company have an official quality management system in place to } \\
\text { ensure on-site quality? }\end{array}$ & 1 & & 9 \\
\hline 2 & $\begin{array}{l}\text { If your answer to no. } 1 \text { is no, do you have a system in place for ensuring quality } \\
\text { that has been designed by the company? }\end{array}$ & 8 & & 2 \\
\hline 3 & $\begin{array}{l}\text { Do you think that an official quality management system will ensure quality on } \\
\text { building sites? }\end{array}$ & 7 & & 3 \\
\hline 4 & $\begin{array}{l}\text { Would you say that the practice of using subcontractors to do most of the work } \\
\text { has a negative influence on maintaining quality on site? }\end{array}$ & 4 & & 6 \\
\hline 5 & $\begin{array}{l}\text { Do you think that quality is sacrificed in order to complete projects on time and } \\
\text { to maximise profit? }\end{array}$ & 10 & & 0 \\
\hline 6 & $\begin{array}{l}\text { Do you think that the tender system, where the lowest tenderer is accepted most } \\
\text { of the time, contributes to poor quality? }\end{array}$ & 9 & & 1 \\
\hline \multirow[t]{2}{*}{7} & $\begin{array}{l}\text { Which of the following aspects have, in your opinion, a negative impact on } \\
\text { quality on South African building sites (in general, not only on your projects) } \\
\text { Please indicate on a scale of } 3 \text {, with } 3 \text { being the most negative: }\end{array}$ & & & \\
\hline & & $\mathbf{1}$ & 2 & 3 \\
\hline 7.1 & Lack of training of labour & 0 & 1 & 9 \\
\hline 7.2 & Lack of supervision & 0 & 7 & 3 \\
\hline 7.3 & Insufficient time for completion & 0 & 8 & 2 \\
\hline 7.4 & Lack of commitment by top management & 6 & 3 & 1 \\
\hline 7.5 & Insufficient detailing/specification by architects & 3 & 5 & 2 \\
\hline 7.6 & Quality of material & 6 & 4 & 0 \\
\hline 7.7 & $\begin{array}{l}\text { Culture of labour (i.e. not in their culture to take responsibility for the quality } \\
\text { of their own work) }\end{array}$ & 1 & 1 & 8 \\
\hline 7.8 & Unrealistic expectations by owners and/or architects & 2 & 7 & 1 \\
\hline
\end{tabular}

\section{Discussion}

The following deductions can be made from the above research:

- Although most of the respondents do not have a formal quality management system in place, all claim to have some in-house system to ensure quality. Furthermore most respondents believe that a formal quality management system will ensure better quality on building sites (questions 1, 2 and 3).

- The respondents were divided in their opinion whether the procedure of using subcontractors has a negative influence on maintaining quality on site, therefore differing from the results in Zietsman's [14] study (question 4).

- All the respondents agreed in question 5 that quality is sacrificed in order to complete projects on time and to maximise profit. This is in agreement with Zietsman [17] who mentioned that there should be better communication between contractors and clients to eliminate unrealistic time schedules.

- Almost all respondents were in agreement with Zietsman [17] that the traditional tender system contributes to poor quality (question 6).

- Nine out of the ten respondents felt strongly that lack of training has a negative impact on quality (question 7.1) and a little less strongly about the lack of site supervision (question 7.2).

- In question 7.3 most respondents were not so negative about insufficient time for the completion of projects. This in a way contradicts the response in question 5. 
- Lack of commitment by top management (question 7.4) was not seen as having a negative impact on quality, which does not correspond to the research done by Grobbelaar [3] and Ngowi [10].

- Question 7.5 (insufficient detailing) had a mixed response and did not seem to be a problem.

- Quality of material (question 7.6) also did not seem to be a problem.

- Most of the respondents (seven out of ten) agreed with the study done by Ngowi [10] in Botswana that the culture of labour also has a negative impact on quality on local building sites.

- Respondents were divided in their response to question 7.8 about the influence that unrealistic expectations by owners has on quality.

\section{TOTAL QUALITY MANAGEMENT}

In an effort to be pro-active regarding quality, a Total Quality Management system (TQM) has been implemented in many companies across the world. Ahmed [1] defines TQM as the management approach of an organization, which concentrates on quality based on the participation of its members and aims at long-term success through satisfaction and benefits to all members of the organization and society. TQM involves managing for total quality, effectiveness and competitiveness and requires involvement by every person in the organisation. It is a culture that requires a total commitment to customer satisfaction through continuous improvement and innovation in all aspects of business [9]. TQM supplies a common language for the proper communication required to achieve quality.

TQM is a never-ending process that is aimed at continuous improvement and innovation. Management drives the TQM system. Technical change is not all that is required to institute TQM, but also social changes within the organisation. The process of cultural change must offer an alternative to the current culture, while not creating a void where a new culture should be established.

Total Quality Management requires commitment and involvement from all employees as well as a scientific knowledge about the system [9]. TQM utilises primary, long term strategies and secondary strategies, focussing on operations and profitability, to achieve its goals. There are several management focus areas, tool focus areas and employee focus areas that have to be attended to by the company to achieve the goals of TQM [9].

\section{TOTAL QUALTY MANAGEMENT AND ISO 9000 CERTIFICATION}

Before considering implementation of TQM, one should also consider ISO 9000 certification and how it compares to TQM. Sun et al [14] defines ISO 9000 as " $a$ series of guidelines for companies that establish their quality systems by focussing on procedure, control and documentation”.

Some of the principle differences between ISO 9000 and TQM are the following:

- According to Sun et al [14] the main goal of ISO 9000 is to provide and maintain an effective quality system that will aim to eliminate errors and rework in order to satisfy 
their customers. TQM on the other hand aims to improve quality and customer satisfaction on a continuous basis by involving both the organization and the individual.

- ISO 9000 certification is implemented by quality managers (Sun et al: [14]), while the senior management and other employees are mostly not involved. TQM requires that all members of a company should be involved.

- Sun [13] mentions that ISO 9000 should not be seen as a substitute for TQM; nor should a company be satisfied only with ISO 9000 certification. Sun et al [14] indicate that many researchers have concluded that ISO 9000 should be the stepping stone to TQM and that the changes to ISO 9000 standards that were implemented during the past years, were intended to bridge the gap to TQM.

\section{IMPLEMENTING AND MAINTAINING A TQM SYSTEM IN THE CONSTRUCTION INDUSTRY}

In an effort to see whether some or all of the abovementioned problems in the South African construction industry can be overcome, one may look at implementing and maintaining a TQM system. The following are some of the facts regarding such a system:

According to Crosby [2] there are fourteen steps required for the implementation of a TQM system. These are:

1. Attaining management commitment

2. Establish a quality improvement team

3. Measurement

4. Determining the cost of quality

5. Creation of quality awareness

6. Taking corrective actions

7. Planning for quality

8. Employee education and training

9. Launching

10. Setting goals

11. Error-cause removal

12. Recognition and rewarding

13. Establishing quality councils and quality circles

14. Repetition

These steps need not be done sequentially, as some can be done concurrently, but all steps have to be completed to ensure proper implementation of a TQM system.

The implementation of a Total Quality Management system requires the creation of a quality culture. This process is often uncomfortable, as people are generally afraid of change. The aim of a cultural change must be the creation of a force that drives actions to achieve the vision and goals of TQM [5].

The key parameters for the successful implementation of TQM are the creation of commitment, the creation of cultural change and the empowerment of all employees [5]. Commitment must be created towards the company and its survival. Commitment is manifested in a relentless pursuit of goals regardless of obstacles. The greatest threat to 
successful implementation is an uncommitted management cadre. It is therefore necessary for management to ensure commitment through various activities. These activities can be subdivided into aspects such as permitting, supporting, managing and leading by example.

The need to fulfil personal commitment must foster the belief that the individual is making a positive contribution to the company. This will manifest a constructive dissatisfaction with the current situation, an inspiring vision of the company and a focus on the business goals of the company.

People's resistance to change will only be changed through repeated education and positive reinforcement. Leading by role models and an understanding of the consequences of failure to change are also required. Behaviour is dictated by attitude and, therefore, cultural change must aim at changing attitudes first.

Empowerment will provide every employee with the responsibility and authority to improve quality. It creates effective decision-makers out of the people closest to the problem, resulting in quick action. Empowerment also enables two-way communication. Obstacles to empowerment are based on the traditional mistrust between management and the workforce.

The problem with a TQM system, as with any other system, is that it will not sustain its own momentum. It requires leadership and management to ensure that the cost of quality does not start to increase again. Leadership must see to it that employees act correctly, while management must ensure they execute their tasks effectively.

Leadership provides the basis for company-wide participation. Leadership in the company motivates through the use of effective communication, a relevant recognition and reward system and the continued empowerment of all employees. Management must use team building and training and education to sustain the TQM system.

Motivation through recognition and rewards operates on the basis of influencing future performance with positive reinforcement. Recognition and rewards change quality-value statements into attitudes. Employees from all levels of the organisation must administer the recognition and reward system to ensure credibility and transparency. The timing of the recognition and rewards is important and must allow for regular intervals between awards [5]. There are many forms of recognition and rewarding. The level and status of the employee must also be considered when deciding on the most applicable recognition or reward.

Continued empowerment must be utilised to enable employees to feel, accept and discharge responsibility [11]. This will ensure effective participation in and contributions to the quality process by individuals. The construction industry already has, through its nature of decentralised activity points, the structure to allow empowerment. Care must be taken not to counteract empowerment through the prescription of standard solutions to unique problems, as is typical of this industry. Empowerment requires trust, and trust can only be achieved through team building.

It is impossible for a single person to control a modern construction project. A team, focussed on producing a quality building, is required to complete a project successfully. There are many benefits from effective teamwork, including improved productivity and problem 
solving, due to the availability of a larger pool of knowledge, skills and experience within a team [6]. If it wants to reap these benefits, management must ensure an environment where a team is informed, has the authority and autonomy to act and where success is acknowledged [5].

Employees must be encouraged towards self-improvement through education and training. This will ensure personal and professional growth with major benefits to the company. A continued, low-level barrage of communication on quality will keep it in the forefront of the employee's mind [2].

All levels of employees must be trained and educated. This must be done to ensure top management remains committed to the quality process [8], to keep managers anxious to achieve the benefits of improved quality [11], to give supervisors the necessary people skills and to keep the general workforce aware and committed to the TQM system. Training must also be aimed at improving the personal conditions of the poor of South Africa, many of whom are employed in the construction industry.

The content of training must take the knowledge, skills and attitudes in possession of and those required from the trainee into consideration. Training and education may focus on concepts, processes or tools and techniques, depending on the level of employee being trained [8]. The venue of training must, likewise, be determined with level of employee, time available and availability of trainers in mind.

\section{SUMMARY AND RECOMMENDATIONS}

Now that the problems regarding quality in the South African construction industry have been identified and the theory of TQM has been discussed, the question one should address is whether the implementation of TQM by contractors in South Africa will solve these problems.

Since very few South African construction companies have formal quality certification (i.e. ISO 9000) few studies have been done regarding the formal use of TQM principles by South African construction companies, and it became necessary to look at what the situation was in overseas countries.

Shammas-Toma et al [12] carried out a study in 1996 on the obstacles to implementing TQM in the United Kingdom's construction industry. Some of their findings were as follows:

- Quality achieved on 25 construction projects in the study generally fell below the required standards, despite the fact that all contractors involved in the study had quality control procedures in operation and all but two of them were certified to the BS 5750 Standards.

- The TQM emphasis on prevention rather than detection of defects was notably absent.

- There was no evidence to suggest that top management was committed to quality. Cost and profitability were the forces driving the policies enacted on the projects studied.

- The culture, far from being devoted to quality improvement, was dominated by short-term financial considerations, reflected in uncooperative and suspicious relationships.

- Measurable quality criteria against which improvements could be monitored were absent. 
Having said the above, it is possible that TQM can reverse the trend of bad quality, lack of trust and adversarial relations. Ahmed [1] states it as follows: "Although not a magic pill or panacea for all illness, it will, if properly implemented, help construction companies improve and will help all parties come closer"

Supporting the latter, Joubert [7] mentioned that when the future of any construction company in South Africa is being considered, specifically with regard to increased competition and the ability to secure follow-up or negotiated work, the following recommendations should be kept in mind.

- Invest in the preventative cost of quality i.e. implementing a TQM system, as the benefits received in the long run will far outweigh the initial investment. Failure to act altogether will result in even greater costs.

In taking this bold step, he further recommends:

- Do not attempt to implement a TQM system without the genuine commitment of the entire executive level of management.

- Designate a committed and energetic champion who will lead the quality improvement process for an extended period of time.

- Appoint a specialist to assist with planning the implementation process and, if possible, keep the specialist to guide the process itself.

- Ensure good communication is maintained throughout the organisation, prior to, during and after the implementation process.

- Elicit the help and support of clients, professionals, suppliers, unions and sub-contractors in the quality improvement process.

- Amend contract agreements with clients, suppliers and sub-contractors to ensure alignment with the TQM goals and procedures.

- Be realistic regarding the time required to implement the TQM system, as it is a long and arduous process.

- Remember that quality improvement does not have a completion date.

- Celebrate successes and learn from mistakes.

\section{CONCLUSION}

The above survey reveals a gross neglect of quality management in the South African construction industry. The theories and full methodologies for implementing quality systems are available, both internationally and locally. The international community has gone past quality management as a control system to Total Quality Management as a management system and a culture and even beyond that to Six Sigma, i.e. process improvement to finite parameters of tolerable defects - all to improve services to customers.

Looking ahead from the present and predicted future boom in the local construction industry and to 2010, in particular, vast opportunities loom in South Africa. These will lead to severe competition from abroad. Local companies will thus have to be extremely competitive to enable them to compete in such an environment. Another way to counter this could be through partnering and even alliances with international companies. To be able to survive on 
their own or take full advantage of such arrangements, South African companies should have the necessary systems and cultures in place.

From the current position and options, it is abundantly clear that South African companies can absolutely not postpone the institution of adequate systems any longer.

\section{REFERENCES}

[1] Ahmed, SM. Undated. Measurement of construction processes for continuous improvement. Revised final report to the State of Florida, Department of community affairs.

[2] Crosby, PB. 1979. Quality is free. New York: McGraw-Hill, Inc.

[3] Crosby, PB. 1984. Quality without tears. New York: McGraw-Hill, Inc.

[4] Grobbelaar, S. 2001. Die kwaliteitsvereistes van die ISO 9000: 2000 dokumentasie en die invloed daarvan op die konstruksiebedryf. Unpublished BSc (QS) dissertation, University of Pretoria, RSA

[5] Hradesky, J.L. 1995. Total Quality Management Handbook. New York: McGraw-Hill, Inc.

[6] Humphrey, J and Halse, F. 1991. Kenwyn: Juta \& Co, Ltd.

[7] Joubert, W. 2002. The implementation and maintenance of a total quality management system in South African construction companies. Unpublished MSc (Project Management) dissertation, University of Pretoria, RSA

[8] Juran, J.M. 1989. Juran on Leadership for Quality: An Executive Handbook. New York: The Free Press

[9] Kerzner, H. 1998. Project Management: A systems approach to planning, scheduling, and controlling. $6^{\text {th }}$ edition. New York : Van Nostrand Reinhold.

[10] Logothetis, N. 1992. Managing for Total Quality: From Deming to Taguchi and SPC/N. Hertfordshire: Prentice Hall International (UK) Ltd.

[11] Ngowi, AB. 2001. Impact of culture on the application of TQM in the construction industry in Botswana. International journal of Quality and Reliability management. MCB University press.

[12] Oakland, J.S. 1989. Total Quality Management. $2^{\text {nd }}$ ed. Oxford: Butterworth-Heineman Ltd

[13] Shammas-Toma M, Seymour D and Clark, L. 1998. Obstacles to implementing TQM in the UK construction industry. Construction management and economics. E \& FN Spon

[14] Sun, H. 2000. Total Quality Management, ISO 9000 certification and performance improvement. International journal of Quality and Reliability management. MCB University press.

[15] Sun, H, Li, S and Ho, K. 2004. The trajectory of implementing ISO 9000 standards vs. total quality management in Western Europe. International journal of Quality and Reliability management. MCB University press.

[16] Townsend, P.L. and Gebhardt, J.E. 1990. Commit to Quality. New York: John Wiley \& Sons

[17] Verster, JJP. 1998. Strategies for successfully meeting the demands of quality and service excellence. Acta Structillia. Journal for the physical \& development sciences, University of the Free State, Bloemfontein, RSA. 
[18] Zietsman, R. 1997. Kwaliteitsbeheer by enkele kontrakteurs in die deeltitelhuisboubedryf in Pretoria en Pietersburg. Unpublished MSc (Real estate) dissertation, University of Pretoria, RSA 